\title{
Complex Processing tailings of the Balkhash Concentrating Factory
}

\author{
Viktor Mikhaylovich Shevko, Gulnara Ergeshovna Karataeva, \\ Galimzhan Mendikaraevich Serzhanov, Alexandra Dmitrievna Badikova \\ and Assiya Salidinovna Abzhanova
}

\author{
South Kazakhstan State University named after M.Auezov, \\ Kazakhstan,160012, Shymkent, Tauke Khan avenue, 5
}

DOI: http://dx.doi.org/10.13005/bbra/1918

(Received: 15 August 2015; accepted: 06 October 2015)

\begin{abstract}
At flotation concentration of copper ores the tailings are formed, which contain both nonferrous metals and a significant amount of silicon and iron. The nonferrous metals from the tailings can be taken by flotation or leaching; but the silicon and iron is used irrationally as a backfilling material in mined-out space. The work purpose was the development of a complex technology of processing the Balkhash concentrating factory's tailings (Kazakhstan) with production of a collective polymetallic concentrate and ferroalloys. The research has been fulfilled by a method of thermodynamic modelling using the software package HSC-5.1 (Outokumpy), a method of rototable experiment planning with regard to the chloride sublimation roasting of the Balkhash concentrating factory's (BCF) tailings (0.27-0.39 \% of $\mathrm{Cu}$; 0,54-2.03 \% of $\mathrm{Zn}$; 0.13-0.5 \% of $\mathrm{Pb}$; 12.35-22.73 \% of Fe; 7.04-13.09 \% of Nà̂̀i; 0.3-1.48 \% of Mgî́; 6.2-11.71 \% of $\mathrm{Al}_{2} \mathrm{O}_{3} ; 0.02-0.011 \%$ of Mo; 0.04-0.07\% of As; 38.49-57.99 \% of $\mathrm{SiO}_{2}$; 0.41-0.58 \% of $\mathrm{Na}$; 0.61-0.74 \% of K; 0.8-1.3\% of S) and electrosmelting cinders after the roasting. It is found, that copper is extracted from the flotation tails by chloride sublimation worse, than zinc and lead. For limitation of iron chloridosublimation it is necessary to carry out the process at 7 -fold oxygen excess and 3-fold $\mathrm{CaCl}_{2}$ one. High degree of nonferrous metals' chloridosublimation (80$89 \%$ of $\mathrm{Cu}, 95-99 \%$ of $\mathrm{Zn},>99 \%$ of $\mathrm{Pb}$ ) and low degree of iron chloridosublimation (1$1.23 \%$ of $\mathrm{Fe}$ ) is observed at $1140-1200^{\circ} \mathrm{C}$ during $39-60 \mathrm{~min}$ and the surplus of $\mathrm{CaCl}_{2}$ in 3,2 times. Electrosmelting the cinders of the chloride sublimation roasting of the Balkhash concentrating factory's (BCF) flotation tailings in a mix with coke and quartzite allows to produce a ferroalloy with silicon content of $28-63 \%$ (at extraction in the ferroalloy of 80$87.3 \%$ of silicon). Ferrosilicon of a grade of FS50 is formed at the electrosmelting a charge containing $11 \%$ of steel cuttings, $20 \%$ of quartzite from the ore mass and $126-133 \%$ of coke from a theoretically required quantity for the silicon and iron reduction. Ferrosilicon of a grade of FS45 is produced at electrosmelting the cinders in the presence of $20 \%$ of quartzite, 6-11 \% of steel cuttings and 100-106 \% of coke.
\end{abstract}

Keyw ords: Concentration tailings, chloridosublimationà, cinder, electrosmelting, ferroalloy.

At flotation concentration of coppercontaining ores waste products are formed (to 98 $\%$ on 1 tonne of the ore (Samygin, Filipov, \& Shehkirev ,2003; Morozov, Abdykirova, \& Falei, 2015)). Now a quantity of flotation wastes only on the Balkhash and Dzhezkazgan concentrating

* To whom all correspondence should be addressed. factories makes nearly $1 \mathrm{bn}$ t. These wastes, occupying considerable ground areas (approximately $40 \mathrm{~km}^{2}$ for the Balkhash factory), not only make worse environmental ecology, but also contain a significant amount of valuable metals. Kazakhstan produces 360-390 ths t of copper (Alshapov, 2004; State of Kazakhstan mineral raw material base (2015, February 18); World goods markets (2015, February 18)) and loses annually with the concentration tailings more 6-8 
ths t of copper, 36-48 ths $t$ of zinc, 4-5 ths t of lead, to 500 ths $t$ of silicon and 150 ths $t$ of iron. Therefore the concentration tailings are potential raw materials not only for nonferrous metallurgy, but also for manufacture of iron-silicon alloys. In world practice sufficiently rich tails are processed by secondary flotation and leaching; it allows reextracting no more than $50-60 \%$ of nonferrous metals. In the process, as a rule, a nonmetallic component does not earmark for manufacture of the products in demand (Turkebaev, \& Sadykov,1988; Glazunov, \& Davydov, 1980; Snurnikov, 1986; Enne, Sycheva, Edakina, Bykov, etc., 1992; Rudnev,2004; Vorobyev, \& Iskushina, 1997; Jagin, Davydov, Rudnov, etc., 2001; Golik, 2010). In our opinion a perspective method of processing the Balkhash concentrating factory's tails is a combined chloride electrothermal way allowing to recover not only nonferrous metals, but also to produce ferroalloys of various grades (Rybnikova, Emelyanenko, \& Gorbatova, 2009; Badikova, Shevko, \& Karatayeva, 2015; Shevko, Badikova, Serzhanov, Uteyeva, \& Karataeva, 2014).

The given article contains the research results of nonferrous metals' recovery from the Balkhash concentrating factory's flotation tails using chloride sublimation roasting and manufacture of ferroalloys from the roasting cinders.

\section{METHOD}

\section{Investigated raw material}

For the research performance we have used the BCF's tailings. Chemical content of the tailings (in accordance with the data of the production association "Balkhashstvetmet"): 0.27 $0.39 \%$ of $\mathrm{Cu} ; 0.54-2.03 \%$ of $\mathrm{Zn} ; 0.13-0.5 \%$ of $\mathrm{Pb}$; $12.35-22.73 \%$ of Fe; $7.04-13.09 \%$ of $\mathrm{CaO} ; 0.3-1.48$ $\%$ of $\mathrm{MgO} ; 6.2-11.71 \%$ of $\mathrm{Al}_{2} \mathrm{O}_{3} ; 0.02-0.011 \%$ of Mo; $0.04-0.07 \%$ of As; $38.49-57.99 \%$ of $\mathrm{SiO}_{2} ; 0.41$ $0.58 \%$ of Na; $0.61-0.74 \%$ of $\mathrm{K} ; 0.8-1.3 \%$ of S. According to the results of roentgen-phase analysis fulfilled by means of a device D8 Advance (Bruker), the basic components of the tails are $\mathrm{SiO}_{2}$, $\mathrm{NaCa}_{2} \mathrm{Fe}_{5} \mathrm{Si}_{8} \mathrm{O}_{22}(\mathrm{OH})_{2}, \mathrm{Ca}_{3} \mathrm{Al}_{0,84-0,88} \mathrm{Fe}_{1,16} \mathrm{Si}_{3} \mathrm{O}_{12}$, $\left(\mathrm{K}_{0,82} \mathrm{Na}_{0,18}\right) \quad\left(\mathrm{Fe}_{0,03} \mathrm{Al}_{1,92}\right)\left(\mathrm{AlSi}_{3}\right) \mathrm{O}_{10}(\mathrm{OH})_{2-8}$, $\mathrm{Mg}_{4,882} \mathrm{Fe}_{0,22} \mathrm{Al}_{1,881} \mathrm{Si}_{2,96} \mathrm{O}_{10}(\mathrm{OH})_{8-18}, \mathrm{CaSO}_{4} \cdot 2 \mathrm{H}_{2} \mathrm{O}$, $\mathrm{K}_{0,58} \mathrm{Na}_{0,42} \mathrm{AlSi}_{3} \mathrm{O}_{8}$ and $\mathrm{Na}\left(\mathrm{AlSi}_{3} \mathrm{O}_{8}\right.$ ) (figure 1). Weight loss at the calcination at a temperature of $1200^{\circ} \mathrm{C}$ makes $5 \%$. Initial melting point is $1192^{\circ} \mathrm{C}$, end melting point is $1289^{\circ} \mathrm{C}$ (figure 2).

These data have been got by a differential thermal method by means of a device of synchronous thermal analysis STA 449 F3 Jupiter. The samples were heated to $1300^{\circ} \mathrm{C}$ with heat rate of $15^{\circ} \mathrm{C} / \mathrm{min}$ in a high-purity argon atmosphere. The total amount of inlet gas was kept up within 80 $\mathrm{ml} / \mathrm{min}$. Analysis of the results, obtained with the help of STA 449 F3 Jupiter, was made by means of the NETZSCH Proteus software.

Technical calcium chloride $(96.5 \%$ of $\mathrm{CaCl}_{2}$ ) was used as a chlorinating agent.

Chemical composition of the raw materials used coke: $4.9 \%$ of $\mathrm{SiO}_{2}, 1.5 \%$ of $\mathrm{CaO}, 0.41 \%$ of $\mathrm{MgO}, 1.8 \%$ of $\mathrm{Al}_{2} \mathrm{O}_{3}, 2.2 \%$ of $\mathrm{Fe}_{2} \mathrm{O}_{3}, 0.8 \%$ of $\mathrm{S}$, $1.1 \%$ of $\mathrm{H}_{2} \mathrm{O}, 86 \%$ of $\mathrm{C}, 1.3 \%$ - other; steel cuttings: $98 \%$ of Fe, $0.4 \%$ of S, $1.6 \%$ - other; quartzite: $97 \%$ of $\mathrm{SiO}_{2}, 0.7 \%$ of $\mathrm{CaO}, 0.3 \%$ of $\mathrm{MgO}, 0.7 \%$ of $\mathrm{Al}_{2} \mathrm{O}_{3}, 0.8 \%$ of $\mathrm{Fe}_{2} \mathrm{O}_{3}, 0.2 \%$ of $\mathrm{H}_{2} \mathrm{O}, 0.3 \%$ - other.

\section{Technique of carrying out the research}

The thermodynamic modelling of nonferrous metals' chloridosublimation from the BCF's tailings has been performed with use of the software package ÍSC-5.1 (Outokumpy) based on a principle of the Gibb's energy minimum. For calculations we have used the subprogram "Equilibrium compositions", which allows on the basis of quantitative composition of substances to calculate equilibrium distribution degree of an element between all components of a system (Roine, 2002).

Determination of optimum technological parameters of the nonferrous metals' chloridosublimation from the flotation wastes has been carried out by a method of experiment planning using rototable plans of the second order with the subsequent construction of volume and plane images of independent variables' influence on optimization parameters (chloride sublimation degree of a metal - áchl Me $_{\text {) }}$ (Ahnazarova, \& Kafarov, 1978). Chloride sublimation of $\mathrm{Cu}, \mathrm{Pb}$, and $\mathrm{Zn}$ from the tails has been fulfilled in an air flow in a vertical furnace with carborundum heaters. Before the experiment carrying out the BCF's tailings have been pelletized in a bowl granulator (diameter -0.4 $\mathrm{m}$, height of an edge $-0.08 \mathrm{~m}$ ). A calcium chloride solution is applied as a binder. The pellet granules in diameter $0.8-1.0 \mathrm{~cm}$ were dried at $230-240^{\circ} \mathrm{C}$ during 30 minutes. After the drying the granules in 
diameter of $1 \mathrm{~cm}$ have static durability of $8-12 \mathrm{~kg} /$ granule. The dried granules were placed in a container (a basket) made from an alloy X20H80 (melting point is $1400^{\circ} \mathrm{C}$ ) and were loaded into a vertical resistance furnace. Air was fed in the bottom part of the furnace by means of a compressor "Matens" (Italy) through a regulating cock and a rheometer. The temperature in the furnace was regulated by a platinum-platinum-rhodium thermocouple. The chlorides formed were caught in a gas cooler and a bag filter. The weight of pellet charge loaded $\left(\mathrm{G}_{\text {charge }}\right)$ was 8-10 g. The metals' chloridosublimation degree has been calculated under the formula:

$$
{ }_{\mathrm{chl} M e} \frac{G_{\text {charge }} C_{M e \text { charge }} G_{\text {cinder }} \cdot C_{M e(\text { inder })}}{G_{\text {charge }} C_{M e(\text { charge })}} 100
$$

where

$\mathrm{G}_{\text {charge }}$ and $\mathrm{G}_{\text {cinder }}-\mathrm{a}$ charge mass and a cinder mass accordingly, g;

$\mathrm{G}_{\text {Me(charge) }}$ and $\mathrm{C}_{\mathrm{Me} \text { (cinder) }}$ - a metal content in a charge and in a cinder, $\mathrm{g}$.

The metals' content in the tails and in the cinder was determined by means of a device AAS1 (Germany). Electrosmelting the cinder has been carried out in an arc electric furnace with controlled output (from 0 to 10 of kilovolt-ampere). The cinder with coke and steel cuttings was melted during 5560 minutes in a graphite crucible, which is $10 \mathrm{~cm}$ high and its internal diameter is $7 \mathrm{~cm}$. Diameter of a graphite electrode is $3 \mathrm{~cm}$. The charge weight is 250-280 g. Extraction degree of silicon and iron in an alloy is calculated according to the formula:

$$
\text { Me alloy } \frac{\mathrm{G}_{\text {alloy }} \mathrm{C}_{\text {Me alloy }}}{\mathrm{G}_{\text {cinder }} \mathrm{C}_{\text {Me cinder }}} \times 100
$$

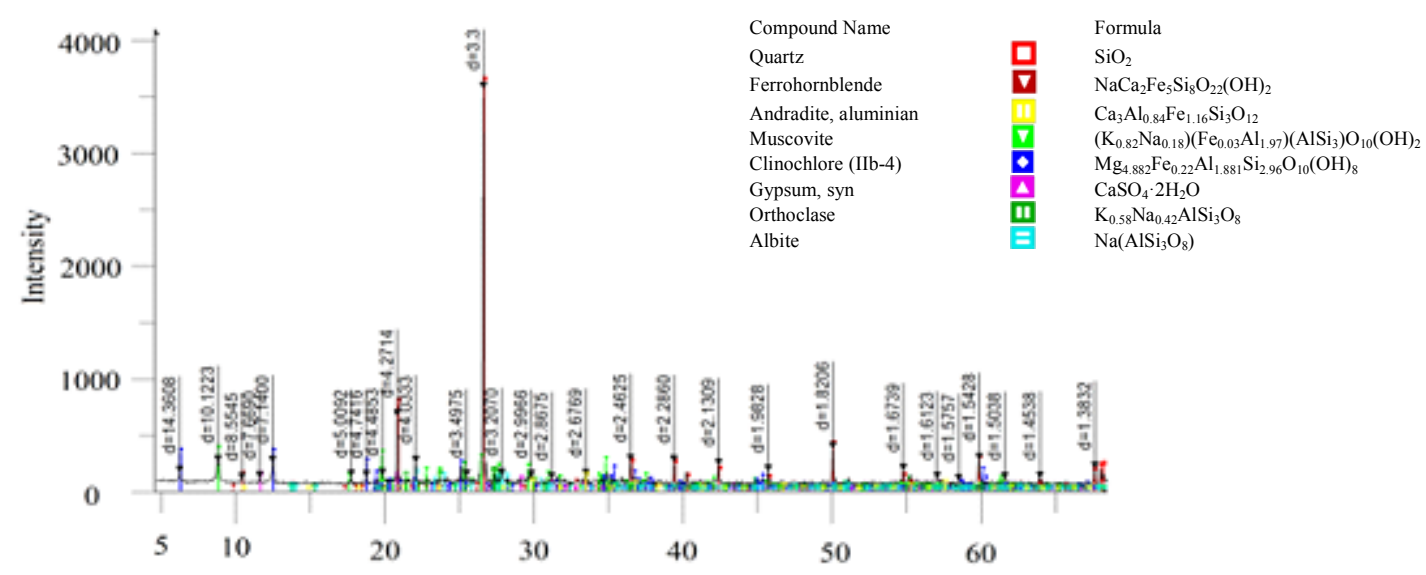

Fig. 1. Radiograph of the BCF's tailings

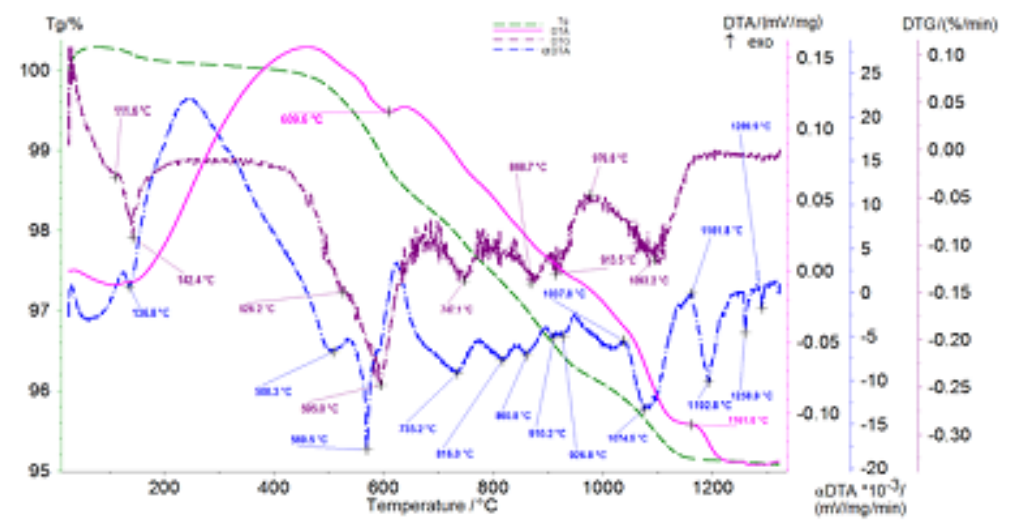

Fig. 2. Derivatogramme of the BCF's tailings 
where

$\mathrm{G}_{\text {cinder }}$ and $\mathrm{G}_{\text {alloy }}$ - a cinder mass and an alloy mass accordingly, g;

$\mathrm{C}_{\mathrm{Me} \text { (cinder) }}$ and $\mathrm{C}_{\mathrm{Me} \text { (alloy) }}$ - a metal content in a cinder and in an alloy accordingly, $\%$.

The silicon content in the alloy was determined by a bottle method using kerosene.

\section{RESULTSAND DISCUSSION}

The information about chloridosublimation of copper, zinc and lead from the BCF's tails in the presence of calcium chloride is represented in Figure 3.

It follows from the figure 3 that at the 3,2fold excess of $\mathrm{CàCl}_{2}$ for the reactions:

$$
\begin{aligned}
& \mathrm{CuS}+\mathrm{CaCl}_{2}+\mathrm{O}_{2}=\mathrm{CuCl}_{2}+\mathrm{CaO} ; \\
& \mathrm{ZnS}+\mathrm{CaCl}_{2}+\mathrm{O}_{2}=\mathrm{ZnCl}_{2}+\mathrm{CaO} ; \\
& \mathrm{PbS}+\mathrm{CaCl}_{2}+\mathrm{O}_{2}=\mathrm{PbCl}_{2}+\mathrm{CaO},
\end{aligned}
$$

increase of the oxygen amount to 7-fold excess somewhat reduces $\alpha_{\text {chl }} \mathrm{Cu}$ (from 93 to $88 \%$ ), slightly influences on $\alpha_{\text {chl }} \mathrm{Zn}(90-92 \%)$ and $\mathrm{Pb}(>$ $99 \%$ ), however in this process undesirable chloridosublimation of iron (as $\mathrm{FeCl}_{2}$ and $\mathrm{FeCl}_{3}$ ) decreases from 10.4 to $2.4 \%$ at $1200^{\circ} \mathrm{C}$.

Table 1 contains the information about influence of independent factors (temperature, $\mathrm{T}$, ${ }^{\circ} \mathrm{C}$; duration of the process, $\tau$, minute; $\mathrm{CaCl}_{2}$ amount, XA, \% from theoretically possible for the reactions 1-3). On the basis of these data using a program Microsoft Excel (Inkov, 2006) we have found adequate regression equations $f(\mathrm{~T}, \tau, \mathrm{XA})$. The regression equations' significance was defined in accordance with the Student's test, and adequacy of the equations - in accordance with the Fisher's test. The following equations were obtained:

$\alpha_{\text {chl }} \mathrm{Cu}=-600.25+0.88 \cdot \mathrm{T}+1.75 \cdot \mathrm{t}+0.048 \mathrm{XA}-3 \cdot 10$ ${ }^{4} \cdot \mathrm{O}^{2}-6 \cdot 10^{-3} \cdot \tau^{2}-4 \cdot 10^{-4} \mathrm{XA}-8 \cdot 10^{-4} \cdot \mathrm{T} \cdot \tau+0.1 \cdot 10^{-3} \cdot \mathrm{T}$

$\cdot \mathrm{XA}+0.1 \cdot 10^{-2} \cdot \tau \cdot \mathrm{XA}$

$\alpha_{\mathrm{chb}} \mathrm{Zn}=-121.44+0.13 \cdot \mathrm{T}+3 \cdot \tau-0.097 \mathrm{XA}-9 \cdot 10^{-3} \cdot \tau^{2}$

$-0.6 \cdot 10^{-4} \cdot \mathrm{XA}^{2}-2 \cdot 10^{-3} \cdot \mathrm{O} \cdot \tau+0.14 \cdot 10^{-3} \cdot \mathrm{T} \cdot \mathrm{XA}+1.01$

$\cdot 10^{-3} \cdot \tau \cdot \mathrm{XA}$

Table 1. The experiment planning matrix and the results of $\mathrm{Cu}, \mathrm{Zn}$ and $\mathrm{Fe}$ chloride sublimation from the tailings of the Balkhash concentrating factory

\begin{tabular}{lccccccccc}
\hline \multirow{2}{*}{$\begin{array}{l}\text { Experiment } \\
\text { number }\end{array}$} & \multicolumn{7}{c}{ Code kind } & \multicolumn{5}{c}{ Natural kind } & $\alpha_{\text {chl }} \mathrm{Cu}, \%$ & $\alpha_{\text {chl }} \mathrm{Zn}, \%$ & $\alpha_{\text {chl }} \mathrm{Fe}, \%$ \\
\hline 1 & $\mathrm{X}_{1}$ & $\mathrm{X}_{2}$ & $\mathrm{X}_{3}$ & $\mathrm{~T},{ }^{\circ} \mathrm{C}$ & $\tau, \min$ & $\mathrm{CaCl}_{2}, \%$ & & & \\
2 & 1 & 1 & 1 & 1159.6 & 51.9 & 275.4 & 78.0 & 89.5 & 1.04 \\
3 & -1 & 1 & 1 & 1040.6 & 51.9 & 275.4 & 53.5 & 80.3 & 0.50 \\
4 & 1 & -1 & 1 & 1159.6 & 28.1 & 275.4 & 61.6 & 82.0 & 0.79 \\
5 & -1 & -1 & 1 & 1040.6 & 28.1 & 275.4 & 35.0 & 65.4 & 0.31 \\
6 & 1 & 1 & -1 & 1159.6 & 51.9 & 144.6 & 67.8 & 76.2 & 0.80 \\
7 & -1 & 1 & -1 & 1040.6 & 51.9 & 144.6 & 45.5 & 67.3 & 0.36 \\
8 & 1 & -1 & -1 & 1159.6 & 28.1 & 144.6 & 56.0 & 70.0 & 0.58 \\
9 & -1 & -1 & -1 & 1040.6 & 28.1 & 144.6 & 31.0 & 57.7 & 0.13 \\
10 & 1.68 & 0 & 0 & 1200 & 40 & 210 & 74.5 & 87.4 & 0.89 \\
11 & -1.68 & 0 & 0 & 1000 & 40 & 210 & 32.6 & 66.1 & 0.21 \\
12 & 0 & 1.68 & 0 & 1100 & 60 & 210 & 66.3 & 80.5 & 0.68 \\
13 & 0 & -1.68 & 0 & 1100 & 20 & 210 & 42.0 & 65.5 & 0.31 \\
14 & 0 & 0 & 1.68 & 1100 & 40 & 320 & 61.0 & 83.2 & 0.80 \\
15 & 0 & 0 & -1.68 & 1100 & 40 & 100 & 42.3 & 68.6 & 0.36 \\
16 & 0 & 0 & 0 & 1100 & 40 & 210 & 57.5 & 76.0 & 0.55 \\
17 & 0 & 0 & 0 & 1100 & 40 & 210 & 55.7 & 75.1 & 0.61 \\
18 & 0 & 0 & 0 & 1100 & 40 & 210 & 56.9 & 74.4 & 0.51 \\
19 & 0 & 0 & 0 & 1100 & 40 & 210 & 58.0 & 76.4 & 0.57 \\
20 & 0 & 0 & 0 & 1100 & 40 & 210 & 57.8 & 76.8 & 0.59 \\
\hline & 0 & 0 & 0 & 1100 & 40 & 210 & 56.2 & 75.8 & 0.60 \\
\hline
\end{tabular}


$\alpha_{\mathrm{chb}} \mathrm{Fe}=-1.912+54 \cdot 10^{-4} \cdot \mathrm{T}+91 \cdot 10^{-3} \cdot \tau-418 \cdot 10^{-3} \cdot \mathrm{XA}$ $+9 \cdot \tau^{2}-114 \cdot 10^{-4} \cdot \mathrm{t}^{2}-3 \cdot 10^{-5} \cdot \mathrm{XA}^{2}+8 \cdot 10^{-6} \cdot \tau \cdot+4 \cdot 10^{-5}$ $\cdot \mathrm{T} \cdot \mathrm{XA}-16 \cdot 10^{-6} \cdot \tau \cdot \mathrm{XA}$.

Similar researches have been performed for the chloride sublimation of lead (in a temperature interval of $\left.800-1000^{\circ} \mathrm{C}\right)$. A regression equation $\alpha_{\text {chl }} \mathrm{Pb}=\mathrm{f}(\mathrm{T}, \tau, \mathrm{XA})$ looks like:

$\alpha_{\text {chl }} \mathrm{Pb}=-1014.1+2.06 \cdot \mathrm{T}+1.79 \cdot \tau+0.31 \mathrm{XA}-1.01 \cdot 10^{-}$

${ }^{3} \cdot \tau^{2}-1.99 \cdot 10^{-2} \cdot \tau^{2}-9 \cdot 10^{-5} \cdot \mathrm{XA}^{2}+46 \cdot 10^{-4} \cdot \mathrm{XA} \cdot \tau-24$

$\cdot 10^{-4} \cdot \mathrm{T} \cdot \mathrm{XA}$.
On the basis of the received equations using the program Mathcad (Ochkov, 2007) a 3D image of a response surface of $\alpha_{\text {chlMe }}$ and its horizontal sections has been constructed for XA = $32 \%$ (smaller amount of $\mathrm{CaCl}_{2}$ does not provide high $\alpha_{\text {chl }} \mathrm{Me}$ ). It follows from the figure 4, that 85 $90 \%$ of $\alpha_{\text {chl }} \mathrm{Cu}$ can be reached in the area fnm (320 $\left.\%, 1174-1200^{\circ} \mathrm{C}, 51.6-60 \mathrm{~min}\right), 95-99 \%$ of $\alpha_{\mathrm{chl}} \mathrm{Zn}-$ in the area $z y x\left(320 \%, 1160-1200^{\circ} \mathrm{C}, 39-60 \mathrm{~min}\right), 90$ $98 \%$ of $\alpha_{\text {chl }} \mathrm{Pb}-$ in the area $u k o\left(320 \%, 920-1000^{\circ} \mathrm{C}\right.$, 41-56 min). As $\alpha_{\text {chl }} \mathrm{Cu}<\alpha_{\text {chl }} \mathrm{Zn}<\alpha_{\text {chl }} \mathrm{Pb}$, that the

Table 2. The experiment planning matrix and the results of electrosmelting the cinder of chloride sublimation roasting the BCF's tailings

\begin{tabular}{|c|c|c|c|c|c|c|c|c|}
\hline \multirow{2}{*}{$\begin{array}{l}\text { Experiment } \\
\text { number }\end{array}$} & \multicolumn{3}{|c|}{ Code kind } & \multicolumn{3}{|c|}{ Natural kind } & \multirow[t]{2}{*}{$\alpha_{\mathrm{Si}}, \%$} & \multirow[t]{2}{*}{$\mathrm{C}_{\mathrm{Si}}, \%$} \\
\hline & $X_{1}$ & $\mathrm{X}_{2}$ & $X_{3}$ & $\mathrm{C}, \%$ & $\mathrm{~S}, \%$ & $\mathrm{Q}, \%$ & & \\
\hline 1 & 1 & 1 & 1 & 139.9 & 12.7 & 15.95 & 81.4 & 51.0 \\
\hline 2 & -1 & 1 & 1 & 110.1 & 12.7 & 15.95 & 68.3 & 44.0 \\
\hline 3 & 1 & -1 & 1 & 139.9 & 3.23 & 15.95 & 74.9 & 57.4 \\
\hline 4 & -1 & -1 & 1 & 110.1 & 3.23 & 15.95 & 60.0 & 51.0 \\
\hline 5 & 1 & 1 & -1 & 139.9 & 12.7 & 4.05 & 67.7 & 44.4 \\
\hline 6 & -1 & 1 & -1 & 110.1 & 12.7 & 4.05 & 53.0 & 35.9 \\
\hline 7 & 1 & -1 & -1 & 139.9 & 3.23 & 4.05 & 52.0 & 52.2 \\
\hline 8 & -1 & -1 & -1 & 110.1 & 3.23 & 4.05 & 42.4 & 46.3 \\
\hline 9 & 1.68 & 0 & 0 & 150 & 8 & 10 & 75.0 & 52.0 \\
\hline 10 & -1.68 & 0 & 0 & 100 & 8 & 10 & 49.6 & 42.0 \\
\hline 11 & 0 & 1.68 & 0 & 125 & 16 & 10 & 73.3 & 49.0 \\
\hline 12 & 0 & -1.68 & 0 & 125 & 0 & 10 & 55.2 & 58.3 \\
\hline 13 & 0 & 0 & 1.68 & 125 & 8 & 20 & 76.3 & 53.0 \\
\hline 14 & 0 & 0 & -1.68 & 125 & 8 & 0 & 53.0 & 37.6 \\
\hline 15 & 0 & 0 & 0 & 125 & 8 & 10 & 66.4 & 48.0 \\
\hline 16 & 0 & 0 & 0 & 125 & 8 & 10 & 65.0 & 47.4 \\
\hline 17 & 0 & 0 & 0 & 125 & 8 & 10 & 67.3 & 47.0 \\
\hline 18 & 0 & 0 & 0 & 125 & 8 & 10 & 64.8 & 48.1 \\
\hline 19 & 0 & 0 & 0 & 125 & 8 & 10 & 65.7 & 46.0 \\
\hline 20 & 0 & 0 & 0 & 125 & 8 & 10 & 67.0 & 46.3 \\
\hline
\end{tabular}

chloridosublimation of copper from the BCF's tailings is a constraint.

At the chloride sublimation roasting of the tails the chloride sublimation of iron is undesirable. At the development of iron chloridosublimation the nonferrous metals' sublimates are polluted by iron chlorides. Therefore it is necessary to define conditions at which $\alpha_{\text {chl }} \mathrm{Me}$ (for the present instance, copper) will has a maximum value, and $\alpha_{\text {chl }} \mathrm{Fe}-$ a minimum one. Figure 5 represents the joint information about $\alpha_{\mathrm{chl}} \mathrm{Cu}$ and $\alpha_{\text {chl }}$ Fe from which follows that high (80-89\%) $\alpha_{\text {chl }} \mathrm{Cu}$ and low (1-1.25\%) $\alpha_{\text {chl }}$ Fe are observed at 1140$1200^{\circ} \mathrm{C}$ during $39-60$ minutes at $320 \%$ of $\mathrm{CaCl}_{2}$ (the area $l t z$ ). For this case á $\mathrm{Zn}$ makes $95-99 \%$ and $\alpha_{\text {chl }} \mathrm{Pb}$ is $>99.0 \%$.

Chemical composition of the cinder formed after the roasting: $48.3 \%$ of $\mathrm{SiO}_{2}, 25.4 \%$ of $\mathrm{Fe}_{2} \mathrm{O}_{3}, 12.6 \%$ of CaO, $1.1 \%$ of $\mathrm{MgO}, 0.9 \%$ of $\mathrm{Na}_{2} \mathrm{O}$ $+\mathrm{K}_{2} \mathrm{O}, 11.0 \%$ of $\mathrm{Al}_{2} \mathrm{O}_{3}, 0.8 \%$ - other.

The experiment matrix of electrosmelting the cinder formed after the tailings' roasting is represented in the table 2. Optimization parameters in this experiment series are: silicon extraction 

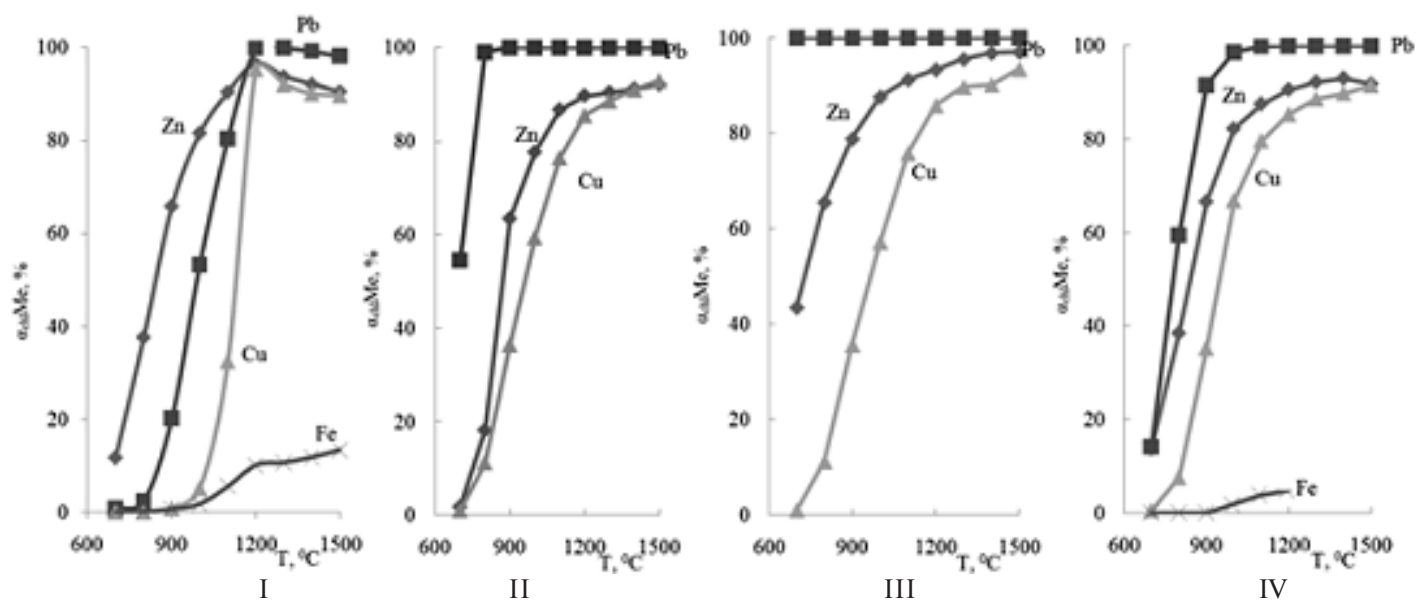

I-without excess of $\mathrm{O}_{2}$, II-2.5-fold excess of $\mathrm{O}_{2}$, III- 5-fold excess of $\mathrm{O}_{2}$, IV- 7-fold excess of $\mathrm{O}_{2}$

Fig. 3. Influence of temperature and oxygen amount on chlorido sublimation degree of copper, zinc, lead and iron from the BCF's tailings

I

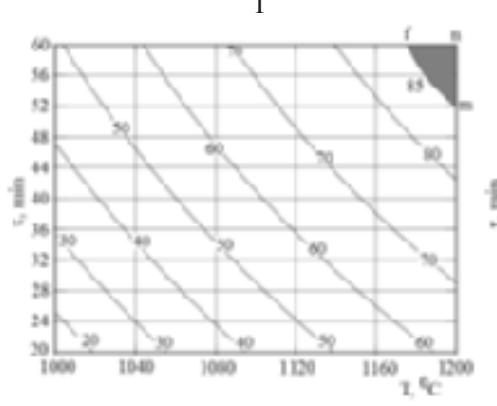

I - copper, II - zinc, III - lead

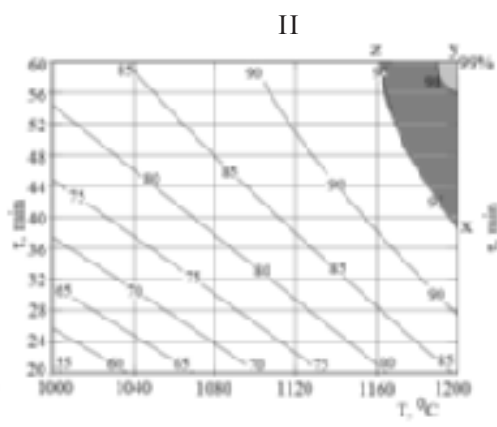

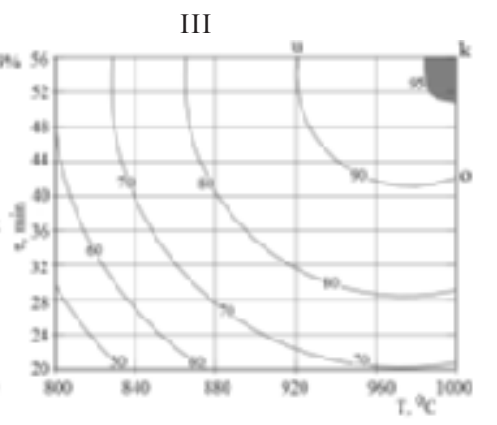

Numbers of lines $-\alpha_{\mathrm{chl}} \mathrm{Me}, \%$

Fig. 4. Horizontal sections of a response surface $-\alpha_{\mathrm{chl}} \mathrm{Me}$

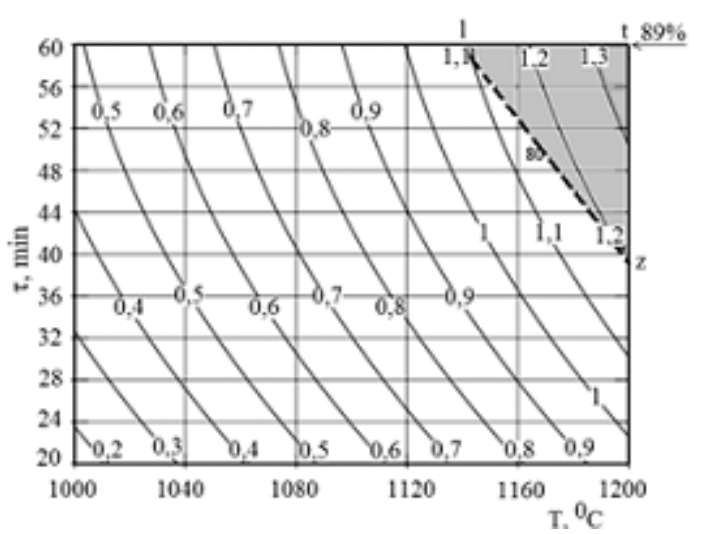

Numbers on lines $-\alpha_{\text {chl }} \mathrm{Fe}(-), \alpha_{\text {chl }} \mathrm{Cu}(-)$

Fig. 5. Combination of $\alpha_{\mathrm{chl}} \mathrm{Cu}$ and $\alpha_{\text {chl }}$ Fe from the BCF's tailings degree in an alloy $\left(\alpha_{\mathrm{Si}}\right)$ and silicon content in an alloy $\left(\mathrm{C}_{\mathrm{Si}}\right)$. Independent factors are: coke amount, $\%$ from all the silicon, which is theoretically required for the iron reduction $(\mathrm{C}, \%)$, steel cuttings amount, \% from weight of the cinder (S, \%), quartzite amount, $\%$ from weight of the cinder (Q). On the basis of the data of the table 2 the following regression equations have been found: $\alpha_{\mathrm{Si}}=-81.078+1.52 \cdot \mathrm{C}+1.186 \cdot \mathrm{S}+0.95 \cdot \mathrm{Q}-0.046 \cdot \mathrm{C}^{2}$ $-0.04 \cdot \mathrm{S}^{2}+8.9 \cdot 10^{-3} \cdot \mathrm{C} \cdot \mathrm{CS}+5 \cdot 10^{-3} \cdot \mathrm{Q} \cdot \mathrm{C}-0.052 \cdot \mathrm{S} \cdot \mathrm{Q}$

$\mathrm{C}_{\mathrm{Si}}=-600.24+0.879 \mathrm{C}+1.75 \mathrm{~S}+0.048 \cdot \mathrm{Q}-3 \cdot 10^{-4} \cdot \mathrm{C}^{2}-$ $6 \cdot 10^{-3} \cdot \mathrm{S}^{2}-4 \cdot 10^{-4} \cdot \mathrm{Q}^{2}-8 \cdot 10^{-4} \cdot \mathrm{C} \cdot \mathrm{S}+1.01 \cdot 10^{-3} \cdot \mathrm{S} \cdot \mathrm{Q} \ldots(11)$

Fig. 6 contains the information on influence of the independent factors on $\mathrm{C}_{\mathrm{Si}}$. It follows from the given figure, that the increase of 


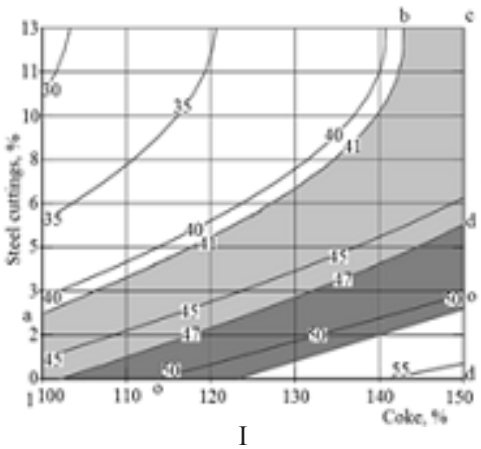

I - without quartzite, II - $10 \%$ of quartzite, III - $20 \%$ of quartzite

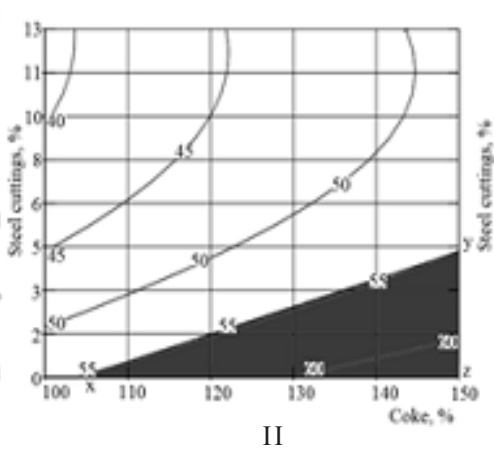

II

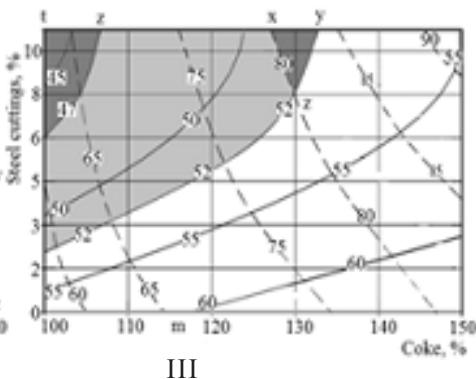

Number on lines $-\alpha_{\mathrm{Si}} \%$

Fig. 6. Effect of coke, quartzite and steel cuttings amounts on $\alpha_{\mathrm{Si}}$

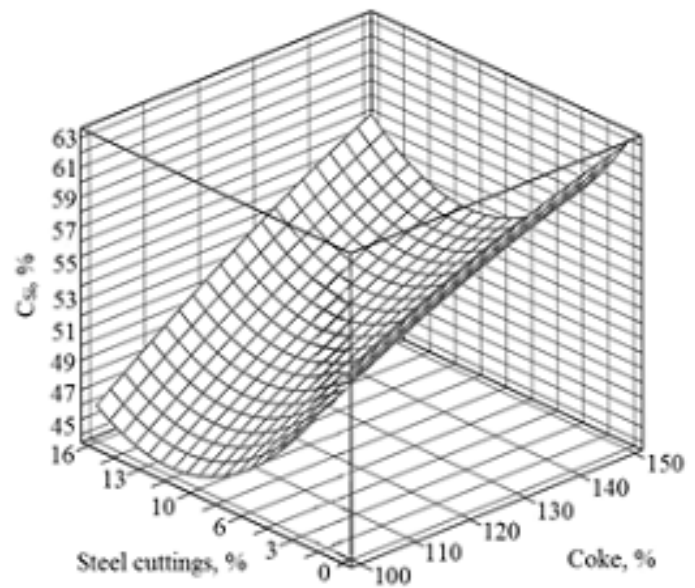

I - a volume image of a response surface

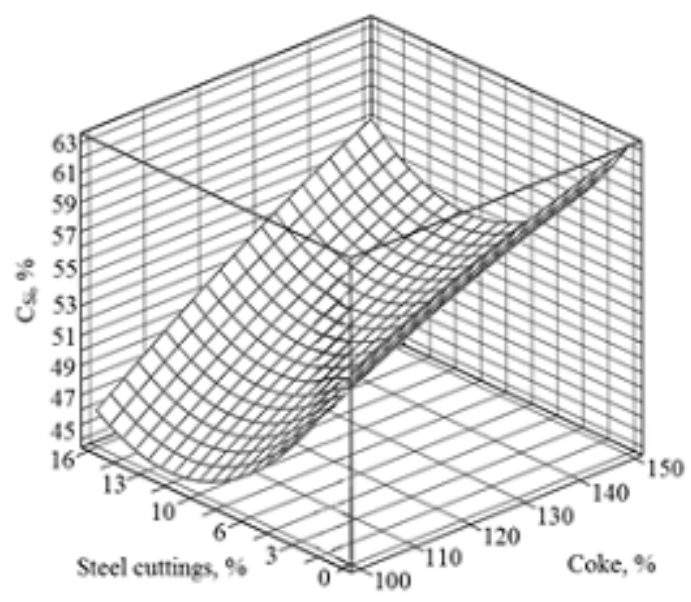

II- horizontal sections of a response surface with isolines of equal degree $\mathrm{C}_{\mathrm{Si}}, \%$.

Numbers on lines $-\alpha_{\mathrm{Si}}(-), \alpha_{\mathrm{Si}}(-)$

Fig. 7. Effect of coke and steel cuttings amounts on $\alpha_{\mathrm{Si}}$ and $\mathrm{C}_{\mathrm{Si}}$ at $20 \%$ of quartzite

steel cuttings amount in the charge leads to the reduction of $\mathrm{C}_{\mathrm{Si}}$, and the increase of coke amount to the growth of $\mathrm{C}_{\mathrm{Si}}$. And the increase of quartzite amount in the charge leads to the growth of silicon content in the alloy formed. Depending on concentrations of the charge's components at the electrosmelting the silicon content in the alloy changes from 28 to $63 \%$. In compliance with (State Standard 1415-93, 1993) now it is supposed that the ferrosilicon corresponding a grade of FS45 is a ferroalloy with silicon content from $41 \%$ to $47 \%$, FS50 - from 47 to $52 \%$, and FS65 - from 63 to $68 \%$ of silicon. At the processing the cinder without quartzite it is possible to obtain ferrosilicon FS45 (the area $a b c d e$ in the figure $6(\mathrm{I})$ ) and ferrosilicon
FS50 (the area edon in the figure 6 (II)). At the increase of quartzite amount the areas of FS45 and FS50 production are displaced towards the increase of steel cuttings consumption and reduction of coke consumption (figures 6 (I) and 6 (II)). However, proceeding from the figure 6 (III) it is impossible to produce ferrosilicon FS65 from the cinder.

It follows from the figure 7 , that at $\alpha_{\mathrm{Si}}=$ $80-83 \%$ the ferrosilicon FS50 is formed in the area zyz (11\% of steel cuttings, $126-133 \%$ of coke, $20 \%$ of quartzite). The ferrosilicon FS45 can be obtain from the cinder in the area tfo (20\% of quartzite, 6 $11 \%$ of steel cuttings, $100-106 \%$ of coke), however in this case $\alpha_{\mathrm{Si}}$ is low $(62-67 \%)$. 


\section{CONCLUSIONS}

a) In the equilibrium state high chloride sublimation degrees of copper ( $88 \%$ ), zinc $(92 \%)$ and lead (>99\%) from the Balkhash concentrating factory's tailings at low degree of iron chloride sublimation $(\leq 2.4 \%)$ are observed at the following conditions: $1200^{\circ} \mathrm{C}$, 3.2-fold $\mathrm{CaCl}_{2}$ excess and 7-fold oxygen excess.

b) At chloride sublimation roasting the granulated tails in air stream $\alpha_{\text {chl }} \mathrm{Cu}<\alpha_{\mathrm{chl}} \mathrm{Zn}$ $<\alpha_{\mathrm{chl}} \mathrm{Pb} ; \alpha_{\mathrm{chl}} \mathrm{Cu}$ is $80-89 \%, \alpha_{\mathrm{chl}} \mathrm{Zn}$ is $95-99$ $\%$, á ${ }_{\text {chl }} \mathrm{Pb}$ is more than $99.0 \%$ and $\alpha_{\text {chl }} \mathrm{Fe}$ makes $1-1.23 \%$ at the following conditions: $1140-1200^{\circ} \mathrm{C}$, duration of the process -39 $60 \mathrm{~min}$ and 3.2-fold $\mathrm{CaCl}_{2}$ excess.

c) Electrosmelting the cinders formed after the chloride sublimation roasting of the Balkhash concentrating factory's tailings in a mixture with coke and quartzite allows to produce a ferroalloy containing $28-63 \%$ of silicon; at the extraction of $80-87.3 \%$ of silicon in the alloy the ferrosilicon FS50 can be obtained at $11 \%$ of steel cuttings, $20 \%$ of quartzite (from the ore weight) and 126$133 \%$ of coke (from the theoretical amount required for the silicon and iron reduction); the ferrosilicon FS45 is formed at the electrosmelting the cinder in the presence of $20 \%$ of quartzite, $6-11 \%$ of steel cuttings and $100-106 \%$ of coke.

\section{REFERENCES}

1. Ahnazarova, S.A., \& Kafarov, B.V., Method of experiment optimization in the chemical industry. Moscow: Higher school, 1978.

2. Alshapov, R.A., Kazakhstan in the world mineral raw material market: Problems and their solving. Almaty, 2004.

3. Badikova, A.D., Shevko, V.M., \& Karatayeva, G.E., Determination of optimum technological parameters of nonferrous metals chloridosublimation from the Balkhash concentrating factory tailings. Complex use of mineral raw material, 2015; 1: 9-15.

4. Enne, S.I., Sycheva, E.A., Edakina, L.A., Bykov, R.A., etc., A combined way of processing concentration tailings of polymetallic ores. Patent of Russian Federation \# 2044079, 1992.

5. Glazunov, L.A., \& Davydov, L.A., Nonferrous metallurgy. Bul. Of STI, 1980; 4: 17-19.

6. Golik, V. I., Scientific basis of innovative technologies of extraction of metals from mill tailings and nonferrous metallurgy. Nonferrous metallurgy, 2010; 5(55-58)

7. Inkov, A.M., Optimization techniques. Shymkent: SKSU, 2006.

8. Jagin, V.P., Davydov, M.A., Rudnov, V.M., etc. Way of a valuable component manufacture from concentration tails. Patent of Russian Federation for an invention \# 2166373, 2001.

9. Morozov, Yu.P., Abdykirova, G.Zh., \& Falei, E.A., Prospect of use of flotation classification at processing flotation tails of sulphide ores. Proceeding of International scientific conference "Resource-saving technologies in ore benefication and nonferrous metal metallurgy" Almaty: Center of Earth Sciences,Metallurgy and Ore Benefication, 2015; 57-59.

10. Ochkov, V.F., Mathcad 14 for students, engineers and designers. Saint Petersburg, S.-Pb.: BHVPeterburg, 2007.

11. Roine, A., Outokumpu HSN Chemistry for Windows. Chemical Reaction and Eguilibrium loft ware with Extensive Thermochemical Database. Pori: Outokumpu Research OY, 2002.

12. Rudnev, B.P., Adoption and development of effective concentration methods of current and old dressing tails of nonferrous metals ores. (The author's abstract of dissertation). Moscow: Ginstvetmet, 2004.

13. Rybnikova, M.V., Emelyanenko, E.A., \& Gorbatova, E.A., Complex leaching concentration wastes of copper-pyrite ores. Theses of reports of International dresser congress, 2009. Russia, Moscow, 2009.

14. Samygin, V.D., Filipov, A.O., \& Shehkirev, D.V., Fundamentals of ore concentration. Moscow: Altex, 2003.

15. Shevko, V.M, Badikova, A. D., Serzhanov, G. M., Uteyeva, R. A., \& Karataeva, G.E., Optimum technological parameters of cooper chloridosublimation from tails of the Balkhash concentration factory. International Conference of Industrial Technologies and Engineering: ICITE 2014 Proceedings. Kazakhstan, Shymkent: South Kazakhstan State University named after M.Auezov, 2014; 126-130.

16. Snurnikov, A.P., Complex use of mineral resources in nonferrous metallurgy. Moscow: Metallurgy 1986.

17. State of Kazakhstan mineral raw material base. (2015, February 18). In Kazakhstan mining portal. Retrieved February 18, 2015, from http:/ /www.mining.kz/component/k2/item/85sostoyanie-mineralno-syrevoj-bazy- 
kazakhstana

18. State Standard 1993; 1415-93, International standard. Ferrosilicon.

19. Turkebaev, E.A., \& Sadykov, G.H., Complex use of raw material and industrial waste. Almaty: Kazakhstan, 1988.
20. Vorobyev, A.E., \& Iskushina T.V., Classification of metals' heap leaching stacks. Mountain journal, 1997; 3(56).

21. World goods markets. (2015, February 18). In World goods markets. Retrieved February 18, 2015, from http: //www. Cmmarket.ru 